\title{
A single-cell view of ammonium assimilation in coral-dinoflagellate symbiosis
}

\author{
Mathieu Pernice ${ }^{1,2}$, Anders Meibom ${ }^{3}$, Annamieke Van Den Heuvel ${ }^{1}$, Christophe Kopp ${ }^{3}$, \\ Isabelle Domart-Coulon ${ }^{2}$, Ove Hoegh-Guldberg ${ }^{1}$ and Sophie Dove ${ }^{1}$ \\ ${ }^{1}$ Coral Reef Ecosystem Laboratory, School of Biological Sciences, The University of Queensland, St Lucia, \\ Queensland, Australia; ${ }^{2} U M R 7208$ 'Biologie des ORganismes et Ecosytèmes Aquatiques' MNHN-CNRS- \\ IRD-UPMC, Paris, France and ${ }^{3}$ Laboratoire de Mineralogie et Cosmochimie du Museum (LMCM), UMR 7202, \\ Museum National D'Histoire Naturelle, Paris, France
}

\begin{abstract}
Assimilation of inorganic nitrogen from nutrient-poor tropical seas is an essential challenge for the endosymbiosis between reef-building corals and dinoflagellates. Despite the clear evidence that reef-building corals can use ammonium as inorganic nitrogen source, the dynamics and precise roles of host and symbionts in this fundamental process remain unclear. Here, we combine high spatial resolution ion microprobe imaging (NanoSIMS) and pulse-chase isotopic labeling in order to track the dynamics of ammonium incorporation within the intact symbiosis between the reefbuilding coral Acropora aspera and its dinoflagellate symbionts. We demonstrate that both dinoflagellate and animal cells have the capacity to rapidly fix nitrogen from seawater enriched in ammonium (in less than one hour). Further, by establishing the relative strengths of the capability to assimilate nitrogen for each cell compartment, we infer that dinoflagellate symbionts can fix 14 to 23 times more nitrogen than their coral host cells in response to a sudden pulse of ammoniumenriched seawater. Given the importance of nitrogen in cell maintenance, growth and functioning, the capability to fix ammonium from seawater into the symbiotic system may be a key component of coral nutrition. Interestingly, this metabolic response appears to be triggered rapidly by episodic nitrogen availability. The methods and results presented in this study open up for the exploration of dynamics and spatial patterns associated with metabolic activities and nutritional interactions in a multitude of organisms that live in symbiotic relationships.
\end{abstract}

The ISME Journal (2012) 6, 1314-1324; doi:10.1038/ismej.2011.196; published online 5 January 2012

Subject Category: microbe-microbe and microbe-host interactions

Keywords: coral; symbiosis; dinoflagellate; isotope; nitrogen; NanoSIMS

\section{Introduction}

Tropical and subtropical coral reefs are among the most productive and biologically diverse marine ecosystems on Earth. The carbonate platforms of the reefs are the result of the strong biomineralizing activity of scleractinian corals, which is supported by their endosymbiosis with dinoflagellates (genus Symbiodinium). This symbiosis occurs in virtually all the reef-building corals living in the photic zone (Venn et al., 2008), on a geographical area of over $280000 \mathrm{~km}^{2}$ (Spalding et al., 2001). The trophic role of such coral-dinoflagellate symbiosis has been investigated since the pioneer work of Muscatine in the late 1960s, who demonstrated that the translocation of photosynthetically fixed carbon

Correspondence: M Pernice, Coral Reef Ecosystem Laboratory, School of Biological Sciences, The University of Queensland, Gehrman Building no. 60, Level 7, St Lucia, Queensland 4072, Australia.

E-mail: m.pernice@uq.edu.au

Received 9 August 2011; revised 21 November 2011; accepted 21 November 2011; published online 5 January 2012 compounds by the dinoflagellates can contribute to most of the metabolic requirements of their coral host (Muscatine, 1990). However, compared with carbon cycling, nitrogen cycling in such symbiosis has been the focus of less attention.

Together, the coral and their dinoflagellate partners are able to acquire inorganic nitrogen, which is advantageous in an environment where planktonic supply may be episodic (Yellowlees et al., 2008; Sheppard et al., 2009). Among the different dissolved nutrients, ammonium is the preferred source of nitrogen for symbiotic corals (Figure 1a) (Grover et al., 2002, 2008). However, the relative contribution of coral and dinoflagellate cells to fix ammonium in this symbiosis has remained unclear. Both the coral host and the algae possess the enzymatic machinery required to incorporate ammonium into their tissues. It has been proposed that the majority of ammonium is assimilated either by the dinoflagellate symbiont via the glutamine synthetase/ glutamine:2-oxoglutarate aminotransferase (GS/ GOGAT) cycle (D'Elia et al., 1983; Roberts et al., $1999,2001)$ or by the coral host via the action of 

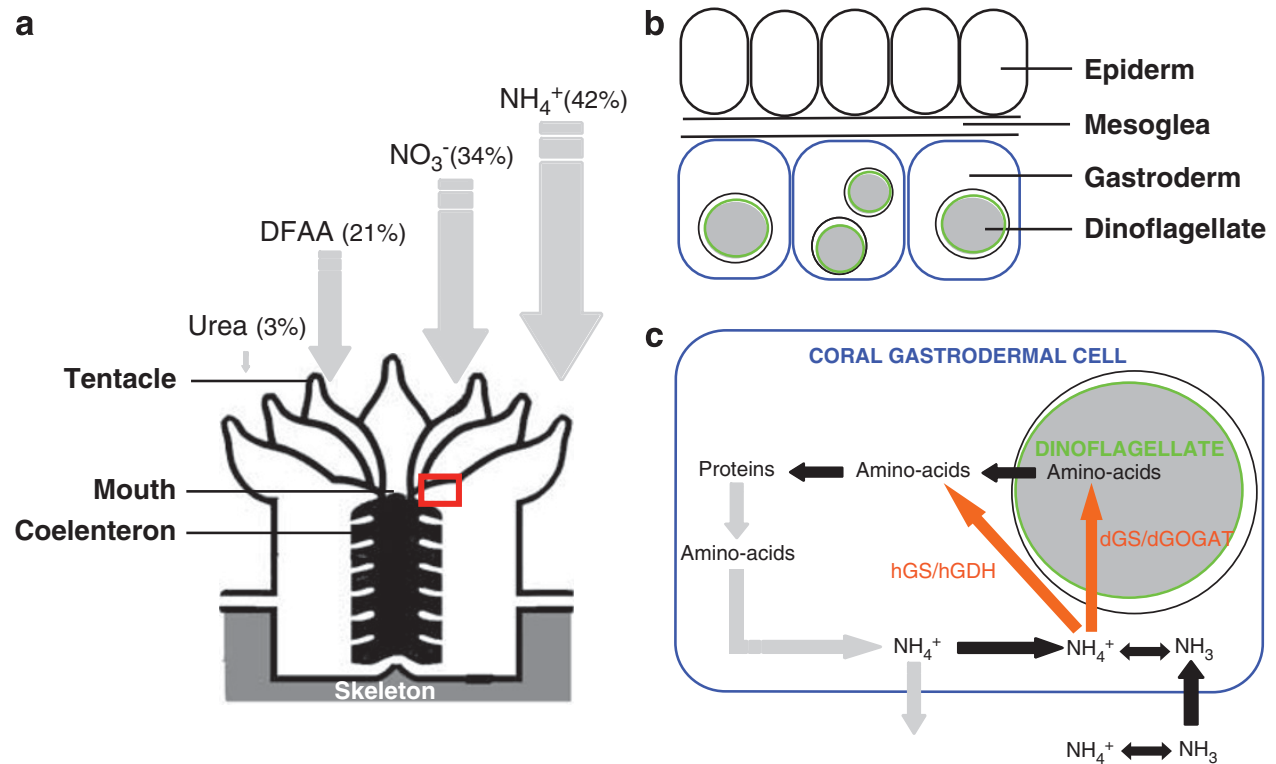

Figure 1 Ammonium as a nitrogen source for corals. (a) Relative contributions of nutrients dissolved in seawater (urea, dissolved free amino acid, DFAA; nitrate, $\mathrm{NO}_{3}^{-}$and ammonium, $\mathrm{NH}_{4}^{+}$) to the nitrogen requirements of corals (Grover et al., 2008). (b) Schematic diagram of coral oral tissues structure (inset of A) indicating the location of the endosymbiotic dinoflagellates in the coral gastrodermal cells. (c) Overview of ammonium cycle within the coral-dinoflagellate endosymbiosis. Orange arrows present the two main hypotheses proposed for ammonium assimilation within the symbiosis (coral host or dinoflagellate symbiont) and the presence of the corresponding enzymes. dGS: dinoflagellate symbiont glutamine synthetase; dGOGAT dinoflagellate symbiont glutamine:2-oxoglutarate aminotransferase; hGS: coral host glutamine synthetase; hGDH: coral host glutamate dehydrogenase. Gray arrows indicate proteins catabolism and excretion pathways.

GS and/or glutamate dehydrogenase (Figure 1c) (Miller and Yellowlees, 1989; Wang and Douglas, 1998; Yellowlees et al., 2008).

The intertwined nature of the coral-dinoflagellate endosymbiosis (Figure 1b), as well as the presence of coral-associated microbial communities have made the relative quantification of host and symbiont contributions to enzymatic processes and metabolic activities extremely difficult. Metabolic studies on coral-dinoflagellate symbioses generally involve the unnatural culture of both symbiotic partners separately or the separation of algal and host tissue fractions, an experimental procedure, which is often incomplete and hampered by crosscontamination (Yellowlees et al., 2008). In this context, recent advances in a high-resolution isotopic imaging technology, the sub-micrometer scale ion microprobe technique referred to as NanoSIMS provides direct imaging and quantification of the metabolic exchanges within an intact symbiosis following stable isotope labeling (Lechene et al., 2006, 2007; Kuypers, 2007; Musat et al., 2008; Dattagupta et al., 2009; Foster et al., 2011). NanoSIMS has recently been successfully applied to reefbuilding corals in order to image trace-elemental distributions in different ultra-structural components of both fossil and living corals (Meibom et al., 2004, 2007, 2008; Clode et al., 2007; Reynaud et al., 2007; Stolarski et al., 2007; Houlbreque et al., 2009; Brahmi et al., 2010). Here, we use NanoSIMS imaging to trace the fixation of isotopically labeled ammonium from seawater within the symbiosis between the reef-building coral Acropora Aspera and the dinoflagellate symbionts Symbiodinium.

In a pulse-chase experiment, fragments from three coral colonies were exposed to ${ }^{15} \mathrm{NH}_{4} \mathrm{Cl}$-enriched seawater $(20 \mu \mathrm{M}$ in final concentration) for $1 \mathrm{~h}$ (the 'pulse' or 'labeling event'). The coral fragments were then transferred to natural seawater with natural isotopic abundances of ammonium and sampled 2, 5 and $11 \mathrm{~h}$, respectively, after the end of the labelingpulse (the 'chase' phase, Supplementary Figure S1) in order to trace ${ }^{15} \mathrm{~N}$-ammonium uptake and incorporation in coral and dinoflagellate cells.

\section{Materials and methods}

\section{Collection and maintenance of corals}

$A$. aspera corals used in this study were collected on the reef flat adjacent to Heron Island Research Station (HIRS, $23^{\circ} 33^{\prime} \mathrm{S} 151^{\circ} 54^{\prime} \mathrm{E}$ ) in April 2009. In all, three separate and healthy colonies of $A$. aspera were divided into single upward-growing branch tips (5-6 cm long) and immediately transferred to flow-through aquaria at HIRS. Coral fragments were then attached to fine nylon fishing line and acclimatized to the mean local ambient temperature for a week in natural seawater in six independent flow-through aquarium tanks (60l; three tank replicates per treatment). The ambient light levels were controlled throughout the experiment using shade cloths to mimic natural reef flat conditions (noon irradiance ranging from 700 to $1000 \mu \mathrm{mol}$ 
photons $\mathrm{m}^{-2} \mathrm{~s}^{-1}$ as measured by Odyssey light loggers; Dataflow, Christchurch, New Zealand).

\section{Labeling experiment}

In order to examine the effect of ${ }^{15} \mathrm{NH}_{4} \mathrm{Cl}$, coral fragments were randomly distributed between the tanks at the time of acclimation and then exposed to two experimental treatments (that is, pulse-chase and control treatments; Supplementary Figure S1). Coral fragments were incubated in artificial seawater in six independent small aquaria (10l; three tank replicates per treatment; close water system; continuously stirred using one powerhead pump for each tank) during the $1 \mathrm{~h}$-pulse period of the experiment. For the pulse-chase treatment, artificial seawater was enriched in ammonium by adding ${ }^{15} \mathrm{NH}_{4} \mathrm{Cl}$ powder to a final concentration of $20 \mu \mathrm{M}$. This concentration is 10 to 20 times above the natural concentration of ammonium in seawater, generally $\leqslant 2 \mu \mathrm{M}$ (Bythell, 1990; Grover et al., 2002), and may represent elevated environmental levels of ammonium caused by nutrients enrichments in coastal waters (Koop et al., 2001). This dose was selected to assess the feasibility and resolution of this methodology and is in the range of concentrations previously used in most of the experimental studies targeting ammonium assimilation in symbiotic cnidarians (Yellowlees et al., 1994; Koop et al., 2001; Roberts et al., 2001; Davy et al., 2006). The ${ }^{15} \mathrm{NH}_{4} \mathrm{Cl}$ powder had an estimated grain size of about $10-100 \mu \mathrm{M}$ and a ${ }^{15} \mathrm{~N}$ isotopic abundance of $98 \%$ (commercially available from Sigma, Castle Hill, NSW, Australia). After the $1 \mathrm{~h}$-pulse period, labeled and control treated coral samples were transferred to natural seawater in six independent flow-through aquarium tanks (60 l; three tank replicates per treatment) for the rest of the experiment period. A subset of coral branches $(n=6)$ was randomly removed from the treatment and control tanks at $T=0,1,3,6$ and $12 \mathrm{~h}$, respectively. Each coral branch was divided into two by using wire cutters; one part was directly snap frozen using liquid nitrogen and stored at $-80^{\circ} \mathrm{C}$ for amino-acids and symbiont density analysis, and a second part was fixed in $1.25 \%$ glutaraldehyde $+0.5 \%$ paraformaldehyde in filtered sea water for further TEM (transmission electron microscopy) and NanoSIMS analyses.

Tissue preparation for TEM and NanoSIMS analyses Coral samples were fixed, embedded in Araldite, cut into $250 \mathrm{~nm}$ sections and mounted onto finder grids for TEM (ProsciTech, Kirwin, QLD, Australia) as described (Supplementary Text S1).

\section{TEM analyses}

The different regions of interest (ROI) within the tissue sections were first imaged and mapped at the Centre for Microscopy and Microanalysis (the University of Queensland, Brisbane, QLD, Australia) using a JEOL JEM1010 Transmission Electron Microscope (JEOL, Frenchs Forest, NSW, Australia) operated at $80 \mathrm{kV}$ accelerating voltage. On the basis of TEM images of coral tissue sections mounted on TEM Finder grids (ProsciTech), the areas of oral tissue presenting both symbiotic dinoflagellate cells, coral host epidermal cells and gastrodermal cells were selected as ROI. These coral tissue sections were subsequently mounted on NanoSIMS holder and coated with calcium and $10 \mathrm{~nm}$ gold for further NanoSIMS analyses.

\section{NanoSIMS analyses}

Tissue sections were imaged with the NanoSIMS ion microprobe at the Muséum National d'Histoire Naturelle in Paris in order to quantify the distribution of newly fixed ${ }^{15} \mathrm{~N}$ within Acropora aspera. The ROI in the coral tissue sections were located by using the camera of the NanoSIMS instrument and the corresponding alpha-numerical code present on each square of the finder grids (letters representing rows and numbers representing columns) in order to ensure further NanoSIMS analysis of the exact TEM imaged areas. The gold-coated TEM sections were bombarded with $16 \mathrm{keV} \mathrm{Cs}^{+}$ions focused to a spot of about $250 \pm 50 \mathrm{~nm}$ on the sample surface, depending on the dimensions of the imaged area and the number of pixels in the image. Secondary molecular ions ${ }^{12} \mathrm{C}^{14} \mathrm{~N}^{-}$and ${ }^{12} \mathrm{C}^{15} \mathrm{~N}^{-}$were simultaneously collected in electron multipliers at a mass resolution $(\Delta \mathrm{M} / \mathrm{M})$ of about 9000 , enough to resolve the ${ }^{12} \mathrm{C}^{15} \mathrm{~N}^{-}$ion from potentially problematic interferences. Charge compensation was not necessary. Images of ${ }^{12} \mathrm{C}^{14} \mathrm{~N}^{-}$and ${ }^{12} \mathrm{C}^{15} \mathrm{~N}^{-}$, respectively, were obtained by rastering the primary beam across the sample with a dwell-time of $1 \mathrm{~ms}$. The ${ }^{15} \mathrm{~N} /{ }^{14} \mathrm{~N}$ ratio distribution was obtained through the ratio of the ${ }^{12} \mathrm{C}^{15} \mathrm{~N}^{-}$image with the ${ }^{12} \mathrm{C}^{14} \mathrm{~N}^{-}$image. ${ }^{15} \mathrm{~N}$-enrichment $\left(\delta^{15} \mathrm{~N}\right.$, in \%o) of individual cells was obtained by comparing the average ${ }^{15} \mathrm{~N} /{ }^{14} \mathrm{~N}$ ratio in selected ROI (circles with a diameter of about $7-10 \mu \mathrm{M}$ for symbiont and host cells) that did not overlap intercellular spaces or the mesoglea, in labeled and unlabeled samples as follows:

$$
\delta^{15} N=\left(\left(N_{\text {mes }} / N_{\text {nat }}\right)-1\right) \times 10^{3}
$$

where, $\mathrm{N}_{\text {mes }}$ is ${ }^{15} \mathrm{~N} /{ }^{14} \mathrm{~N}$ measured in labeled samples by NanoSIMS and $\mathrm{N}_{\text {nat }}$ is the natural abundance of ${ }^{15} \mathrm{~N} /{ }^{14} \mathrm{~N}$ measured in unlabeled samples by NanoSIMS.

Three sections of coral oral tissue were analyzed per time point. Unlabeled coral oral tissue was used as an internal standard.

\section{Physiological measurement}

A total of six coral branches were used for each treatment and each time point in order to assess changes in the physiology of the endosymbiotic dinoflagellates within $A$. aspera. Coral tissue was removed from the samples previously stored at 
$-80^{\circ} \mathrm{C}$ by using the water-picking method with an airbrush and phosphate buffer solution $(0.06 \mathrm{M}$ solution $\mathrm{KH}_{2} \mathrm{PO}_{4}$, pH 6.65). Symbiodinium cells were separated from coral tissue by centrifugation ( $4000 \mathrm{~g}$ for $5 \mathrm{~min}$ at $4{ }^{\circ} \mathrm{C}$ ). The pellet containing Symbiodinium cells was then washed three times to minimize tissue contamination, re-suspended in phosphate buffer solution and used to determine Symbiodinium cell numbers and content in total nitrogen, glutamine and glutamate.

\section{Cell densities of Symbiodinium}

The population density of dinoflagellates was determined using a SEDGEWICK rafter cell 550 haemocytometer (ProSciTech S8050). For each coral branch, the population density of dinoflagellates was estimated by counting and averaging the number of dinoflagellate cells present in 10 subsamples. Briefly, for each subsample, $100 \mu \mathrm{l}$ of sample was added to the edge of the ' $V$ '-shaped notch on the haemocytometer chamber. The counting grid on the haemocytometer consists of nine large squares $(1 \mu \mathrm{l})$ divided into 25 smaller squares $(0.04 \mu \mathrm{l})$. The number of dinoflagellate cells per subsample was counted in a total of 25 smaller squares (total volume of $1 \mu \mathrm{l}$ ). The rest of the pellet containing Symbiodinium cells was used for further analysis of the content in total nitrogen, glutamine and glutamate. Dinoflagellate density was then normalized to the skeletal surface area $\left(\mathrm{cm}^{2}\right)$ of each coral branch by using the melted paraffin technique modified from Stimson and Kinzie (1991).

\section{Nitrogen content and uptake rate}

Nitrogen content (\%) was analyzed in both coral tissue and dinoflagellate in duplicate using standard combustion $\left(950^{\circ} \mathrm{C}\right)$ method (Supplementary Text S1). The nitrogen uptake rate per mg of host tissue or dinoflagellate was calculated according to the equation of Dugdale and Wilkerson (1986), presented in Grover et al. (2002) (Supplementary Text S1).

\section{Glutamine and Glutamate composition}

Amino acids in the samples were separated by reverse-phase high performance liquid chromatography according to the method of Swanson and Hoegh-Guldberg (Swanson and Hoegh-Guldberg, 1998) (Supplementary Text S1).

\section{Statistical analysis}

Statistical analyses were done using the software Statistica 7.0 (Statsoft Inc., Tulsa, OK, USA). Kolmogorov-Smirnov and Levene's test first tested the data for normality and homoscedasticity, respectively. When data deviated from normality and/or were not homogenous, then non-parametric test (Mann-Whitney $U$ - and Kruskal-Wallis-test) was applied instead of the parametric test (one-way analysis of variance (ANOVA) and paired two-tailed $t$-test). Throughout the paper, values given are mean \pm s.d. Results were considered significant at $5 \%$. Glutamine and glutamate data are presented on a $\log _{2}$ scale in order to produce similar visual appearance for up and downregulation.

\section{Results and discussion}

NanoSIMS analysis

NanoSIMS provided detailed images of the ${ }^{15} \mathrm{~N} /{ }^{14} \mathrm{~N}$ ratio that could be correlated directly with TEM observations of the corresponding cell-structures (Figure 2), allowing the detection of specific cellular structures responsible for the fixation of ${ }^{15} \mathrm{~N}$ from ammonium-enriched seawater. Observations indicated a rapid uptake of ${ }^{15} \mathrm{~N}$-ammonium, with ${ }^{15} \mathrm{~N}$ label clearly appearing in the dinoflagellates cells within the $1 \mathrm{~h}$-pulse (Figures 2c and d), and remaining stable throughout the $11 \mathrm{~h}$-chase following the labeling event. By contrast, the ${ }^{15} \mathrm{~N}$-labeling of the coral host tissue remained substantially weaker during the entire experiment (Figure 2).

The dynamics of ammonium incorporation in hospite was followed and quantified by measuring the ${ }^{15} \mathrm{~N} /{ }^{14} \mathrm{~N}$ ratio within individual dinoflagellate cells and within the oral part of the coral host tissue (as illustrated in Figure 3, individual values are given in Supplementary Table S1). In the oral host tissue, ${ }^{15} \mathrm{~N} /{ }^{14} \mathrm{~N}$ ratio was measured separately in epidermal (that is, cells of the coral oral pseudostratified epithelium) and gastrodermal cells by selecting ROI that did not overlap dinoflagellate symbionts, nor inter-cellular spaces or the mesoglea. For each ROI, the average ${ }^{15} \mathrm{~N} /{ }^{14} \mathrm{~N}$ ratio was determined and compared with the corresponding natural (that is, unlabeled) abundance ratios in order to calculate ${ }^{15} \mathrm{~N}$-enrichment.

Dinoflagellate cells present in coral tissue sections displayed a substantial ${ }^{15} \mathrm{~N}$-enrichment after their incubation in enriched seawater (one-way ANOVA $\left.F_{4, \quad 45}=81.34 ; \quad P<0.001\right) \quad$ with a $3600 \pm 200 \%$. ${ }^{15} \mathrm{~N}$-enrichment at the end of the $1 \mathrm{~h}$-pulse $(t=1 \mathrm{~h}$, relative to the natural abundance, Unequal $\mathrm{N}$ Honestly Significant Difference (HSD) $P<0.001$ ), followed by a slight increase in the first $5 \mathrm{~h}$ of the chase $\left(4770 \pm 1180 \%{ }^{15} \mathrm{~N}\right.$-enrichment at $t=3 \mathrm{~h}$ relative to the natural abundance, Unequal $\mathrm{N}$ HSD $P<0.001$ ) and finally accompanied by a plateau from $6 \mathrm{~h}$ onward $\left(6100 \pm 910\right.$ and $6790 \pm 1460 \%{ }^{15} \mathrm{~N}-$ enrichment at $t=6 \mathrm{~h}$ and $t=12 \mathrm{~h}$, respectively, relative to the natural abundance, Unequal N HSD $P<0.001$, Figure 3e). These results emphasize two important points. First, the dinoflagellate symbionts rapidly absorbed nitrogen during the $1 \mathrm{~h}$-pulse of seawater enriched in ammonium. Because unicellular Symbiodinium live within the cells of the host gastrodermis, which line the gastric cavity also named coelenteron (see Figure 1a), the short 
1318

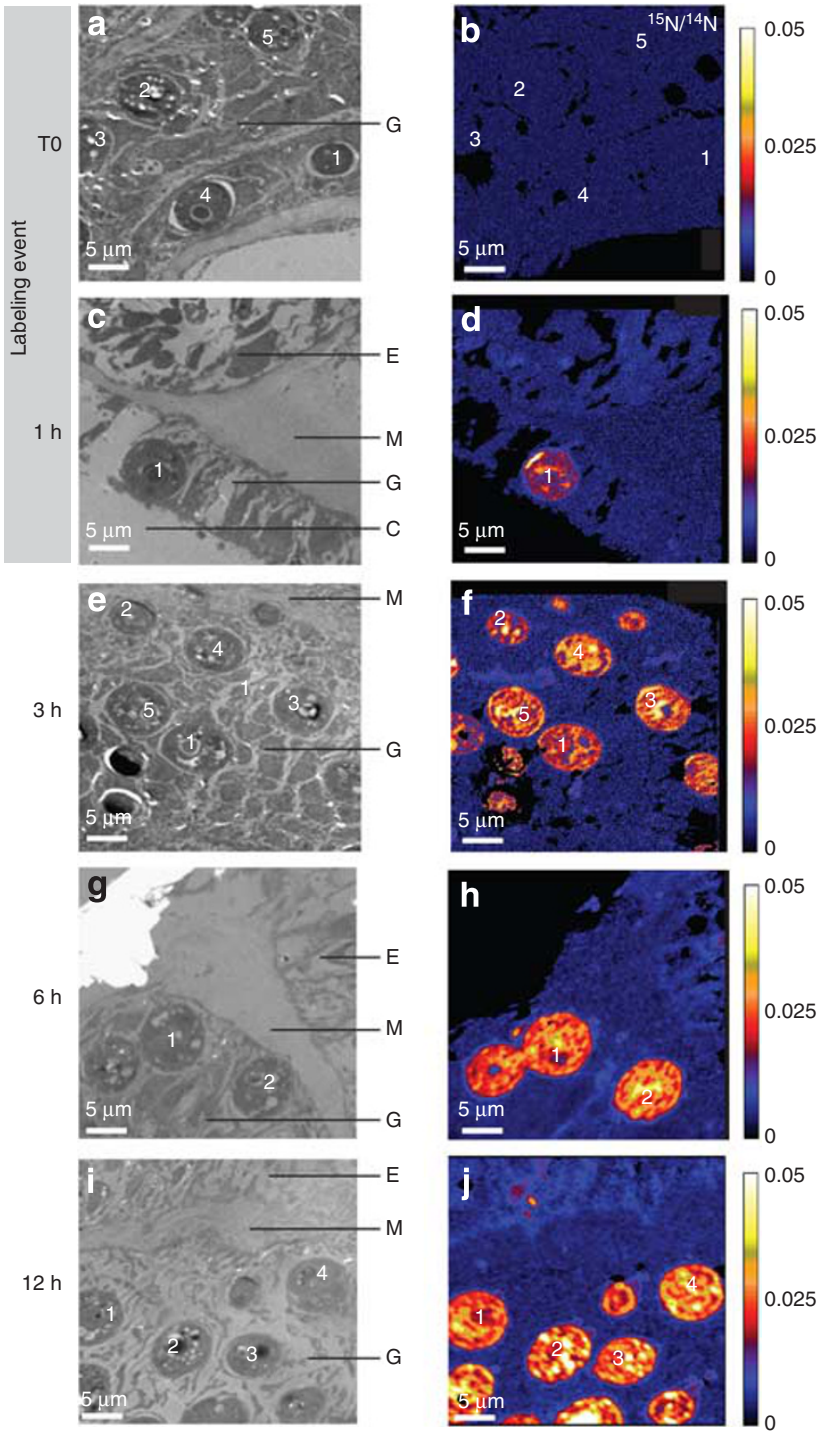

Figure 2 Imaging of ${ }^{15} \mathrm{~N}$-ammonium uptake within the reefbuilding coral Acropora aspera. (a, c, e, g, i) TEM images and (b, $\mathbf{d}, \mathbf{f}, \mathbf{h}, \mathbf{j})$ distribution of ${ }^{15} \mathrm{~N} /{ }^{14} \mathrm{~N}$ as measured by NanoSIMS in the same sections of $A$. aspera tissue during the time series of the pulse-chase labeling experiment. a-b: $t=0$, no label; $\mathrm{c}-\mathrm{d}$ : $t=1 \mathrm{~h}$; $\mathrm{e}-\mathrm{f}: t=3 \mathrm{~h} ; \mathrm{g}-\mathrm{h}: t=6 \mathrm{~h} ; \mathrm{i}-\mathrm{j}: t=12 \mathrm{~h}$. Individual dinoflagellate symbionts that have absorbed ${ }^{15} \mathrm{~N}$ are clearly visible within the coral gastrodermal tissue after $1 \mathrm{~h}$. C, Coelenteron; G, gastroderm; E, epiderm; M, mesoglea. For each NanoSIMS image, the increase in ${ }^{15} \mathrm{~N} /{ }^{14} \mathrm{~N}$ of each individual dinoflagellate symbionts is given in the Supplementary Table S1.

timescale on which the ${ }^{15} \mathrm{~N}$-label reached the symbiont formally supports the hypothesis that the ammonium taken-up and fixed by dinoflagellates derives from the seawater filling the coelenteron and is rapidly transported through coral host tissue as suggested by D'Elia (D'Elia et al., 1983). Part of the ${ }^{15} \mathrm{~N}$-label present in dinoflagellate cells might also come from the fixation of ${ }^{15} \mathrm{~N}$-ammonium by the coral host into ${ }^{15} \mathrm{~N}$-amino acids subsequently transferred to the algal cells. Second, once the plateau was attained, ${ }^{15} \mathrm{~N}$-enrichment in dinoflagellate cells did not decrease over the $11 \mathrm{~h}$-chase period
(Figure 3e). This particular result indicates that (i) there was no further incorporation of unlabeled nitrogen in dinoflagellate cells during this time and that (ii) the symbionts retained most of the ${ }^{15} \mathrm{~N}$-ammonium derived compounds.

Quantitative analysis of the ${ }^{15} \mathrm{~N} /{ }^{14} \mathrm{~N}$ ratio indicated significant ${ }^{15} \mathrm{~N}$-enrichment in both epidermal and gastrodermal host cells after incubation in enriched seawater $\left(460 \pm 150\right.$ and $280 \pm 80 \%{ }^{15} \mathrm{~N}$ enrichment for epidermal and gastrodermal cells, respectively at $t=1 \mathrm{~h}$ relative to the natural abundance; one-way ANOVA $F_{4,154}=51.25 ; P<0.001$ for epidermal cells, Unequal N HSD $P<0.01$; one-way ANOVA $F_{4,95}=47.98 ; P<0.001$ for gastrodermal cells, Unequal N HSD $P<0.01$, Figure 3e). This ${ }^{15} \mathrm{~N}$-enrichment was 8 to 13 times less than the one observed in the dinoflagellate symbionts, but it suggests that the coral host has the capacity to directly assimilate ammonium from enriched seawater (Miller and Yellowlees, 1989; Szmant et al., 1990; Yellowlees et al., 1994; Wang and Douglas, 1998; Lipschultz and Cook, 2002). A way to investigate this hypothesis would be to use NanoSIMS to precisely measure ammonium assimilation rates in individual cell types of coral free of symbionts (experimentally bleached) or incubated in prolonged darkness (Wilkerson and Muscatine, 1984).

After the ${ }^{15} \mathrm{~N}$-ammonium pulse, the proportion of ${ }^{15} \mathrm{~N} /{ }^{14} \mathrm{~N}$ in coral host tissue remained constant with the exception of an increase in ${ }^{15} \mathrm{~N}$-enrichment of coral epidermal cells, $11 \mathrm{~h}$ after the labeling event $(390 \pm 260 \%$ increase at $t=12 \mathrm{~h}$ compared with $t=6 \mathrm{~h}$ for epidermal cells, Unequal N HSD $P<0.005 n=29$ and $n=10$ for 12 and $6 \mathrm{~h}$ respectively; Figure 3e). This particular result is consistent with the hypothesis that nitrogen derived-compounds may be transferred from the dinoflagellate symbionts to the coral host only some time after their synthesis (Wang and Douglas, 1999).

The difference between the ${ }^{15} \mathrm{~N}$-enrichment of epidermal cells and gastrodermal cells within coral host oral tissue (two-way ANOVA, interaction fraction-time: $\left.F_{4,249}=13.46, P<0.001\right)$ was intriguing, with the relative ${ }^{15} \mathrm{~N}$-increase being significantly greater in the epiderm than in the gastroderm, suggesting differential dynamics of ${ }^{15} \mathrm{~N}$-ammonium incorporation in these two oral tissue layers. These significant differences could be the result of (i) a differential access to ${ }^{15} \mathrm{~N}$-ammonium from seawater, epidermal cells being in direct contact with seawater, whereas the gastrodermal cells line the coelenteron internal cavity and/or (ii) the presence of microbial population associated to the coral epidermal tissue. For instance, metagenomic analysis of the coral holobiont Porites astreoides indicates potential fungal assimilation of ammonium for use in biosynthesis (Wegley et al., 2007); in addition, ammonium-oxidizing and nitrifying bacteria might be present within this coral tissue layer and involved in the overall oxidation of ammonium to 


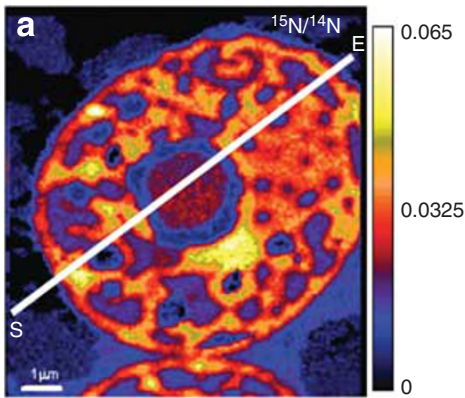

b
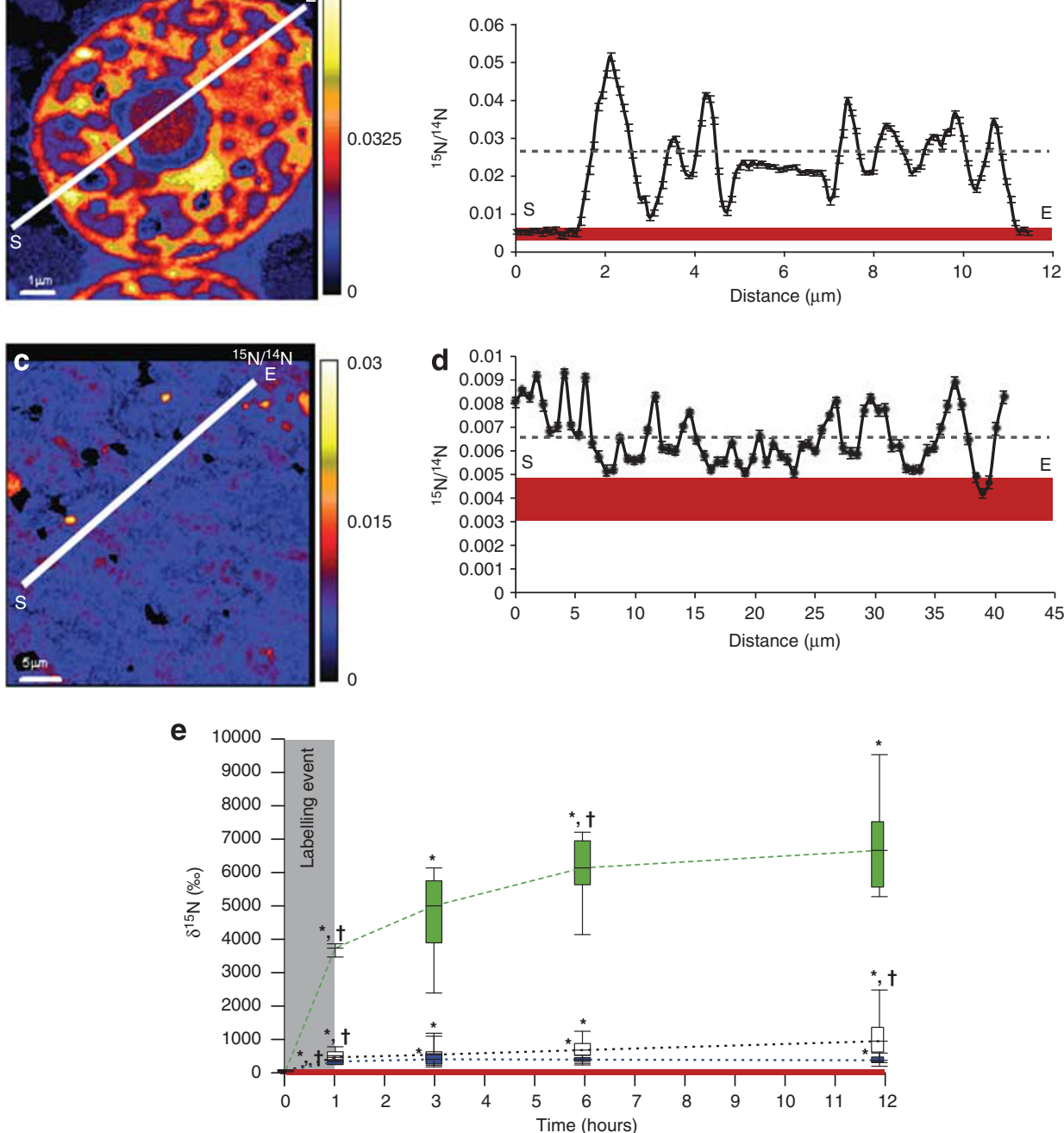

Figure 3 Quantification of nitrogen uptake by individual coral and dinoflagellate cells within the reef-building coral $A$. aspera in response to a pulse of seawater enriched in ${ }^{15} \mathrm{~N}$-ammonium. (a) High resolution NanoSIMS image of the ultrastructural distribution of ${ }^{15} \mathrm{~N} /{ }^{14} \mathrm{~N}$ in a dinoflagellate symbiont. (b) Spatial fluctuations of ${ }^{15} \mathrm{~N} /{ }^{14} \mathrm{~N}$ ratios over the transect indicated in (a), the average ${ }^{15} \mathrm{~N} /{ }^{14} \mathrm{~N}$ ratio measured in this dinoflagellate is indicated by the dashed line. (c) High resolution NanoSIMS image of the ultrastructural distribution of ${ }^{15} \mathrm{~N} /{ }^{14} \mathrm{~N}$ in coral host tissue (epiderm). (d) Spatial fluctuations of ${ }^{15} \mathrm{~N} /{ }^{14} \mathrm{~N}$ ratios over the transect indicated in (c), the average ${ }^{15} \mathrm{~N} /{ }^{14} \mathrm{~N}$ ratio measured in this region of interest is indicated by the dashed line. The red bands in (b) and (d) and their width indicate the fluctuations of the natural ${ }^{15} \mathrm{~N} /{ }^{14} \mathrm{~N}$ ratio in control unlabeled dinoflagellate and coral tissue, respectively. (e) Time series of enrichment in ${ }^{15} \mathrm{~N}$ (\%) measured in individual symbiotic dinoflagellates cells (in green, $n=45$ ), coral epidermal host cells (in white, $n=154$ ) and coral host gastrodermal cells (in blue, $n=95$ ) during the pulse-chase experiment (individual values are given in Supplementary Table S1). ${ }^{*}$ Significant difference (post-hoc Unequal N HSD, $P<0.05$ ) between labeled and control unlabeled samples (red band). ${ }^{\star}$ Significant difference (post-hoc Unequal N HSD, $P<0.05$ ) between labeled samples from two consecutive time points. The box-whisker plot separates the data into quartiles, with the top of the box defining the 75th percentile, the line within the box giving the median, and the bottom of the box showing the 25th percentile. The upper 'whisker' defines the 95th percentile; the lower whisker, the 5th percentile. The red line and its width indicate the maximal fluctuations of the natural ${ }^{15} \mathrm{~N}$-enrichment in coral as measured by NanoSIMS analyses of control unlabeled tissue samples $\left(\delta^{15} \mathrm{~N}=0 \pm 40 \%\right)$.

nitrite to nitrate that could be then assimilated by the coral host (Mohideen et al., 1990; Beman et al., 2007). A few localized ${ }^{15} \mathrm{~N}$-enrichment 'hotspots' were detected in the host epiderm, which could reflect the activity of such microbial communities. However, these intracellular ${ }^{15} \mathrm{~N}$ 'hotspots' appeared only during the 'chase' period (that is, at least $3 \mathrm{~h}$ after the transfer of corals to natural seawater) and, based on high-magnification TEM imaging of corresponding areas, they do not resemble to microbial structures (Supplementary Figure S2). The assumption that the different enrichment observed in epidermal and gastrodermal cells is the result of a differential access to ${ }^{15} \mathrm{~N}$-ammonium from seawater is therefore the most likely. Finally, the occurrence of these ${ }^{15} \mathrm{~N}$ 'hotspots' in the basal part of the coral oral epithelium, an area where granules of glycoproteins have been previously detected (Fautin and Mariscal, 1991) is consistent with an alternative hypothesis involving potential storage of 
nitrogen-derived compounds in the coral host compartment. Further studies are therefore needed to determine precisely the nature of these ${ }^{15} \mathrm{~N}$ 'hotspots'.

Quantification of cell-specific ammonium uptake rate By normalizing the ${ }^{15} \mathrm{~N}$-incorporation to the average nitrogen content of the animal and algal fractions and to the time of incubation following the equation of Dugdale and Wilkerson (1986), it was possible to estimate the ${ }^{15} \mathrm{~N}$ taken up per hour by the host and the dinoflagellate cells, respectively. The symbionts fixed nitrogen during the $1 \mathrm{~h}$-pulse of ammoniumenriched seawater with a specific uptake rate of $504 \pm 28 \mathrm{ng} \mathrm{N} \mathrm{h}^{-1} \mathrm{mg}^{-1}$. Given that this uptake rate is in the range of values found previously in bulk analyses of algal fractions mechanically separated from host tissues (Yellowlees et al., 1994; Grover et al., 2002), it confirms the capabilities of NanoSIMS for in situ imaging and for quantifying the assimilation of nitrogen by individual cells within the coral-dinoflagellate symbiosis. However, it is important to note that this methodology might not be as accurate for tracking the incorporation and transfer of any cellular material within the symbiosis such as, for instance, carbon-derived compounds. Indeed, although chemical fixation of the tissue samples with glutaraldehyde cross-links most of the proteins and amino acids rendering them insoluble, it does not stabilize sugars and other soluble molecules poor in amino groups. Such molecules might thus get extracted during successive steps of sample rinsing and dehydration (Wagner, 2009) and, as a result, ineffectively detected by NanoSIMS. Future studies using this technology to precisely quantify metabolic activities and assimilation of elements other than Nitrogen should therefore use advanced sample preparation methodologies such as, for example, high-pressure freezing in order to effectively immobilize any cellular material (Smart et al., 2010).

\section{Relative contribution of coral and dinoflagellate symbiont to ammonium uptake}

Comparison between host and symbiont uptakerates further allows establishing the relative contribution of dinoflagellate and animal cells to the ammonium fixation capabilities. In this respect, our data indicates that the dinoflagellate cells incorporated 14 to 23 times more nitrogen than coral host cells during the $1 \mathrm{~h}$-pulse of $\mathrm{NH}_{4} \mathrm{Cl}$ (specific uptake rates of: $504 \pm 28 \mathrm{ng} \mathrm{Nh}^{-1} \mathrm{mg}^{-1}, n=15$ for dinoflagellate symbiont; $36 \pm 11 \mathrm{ng} \mathrm{Nh}^{-1} \mathrm{mg}^{-1}, n=52$ for coral host epiderm cells; and $22 \pm 6 \mathrm{ng} \mathrm{Nh}^{-1} \mathrm{mg}^{-1}$, $n=51$ for coral host gastroderm cells; Figure 4 ). This particular result demonstrates a significant heterogeneity in the ability of coral and dinoflagellate cells to fix nitrogen from seawater enriched in

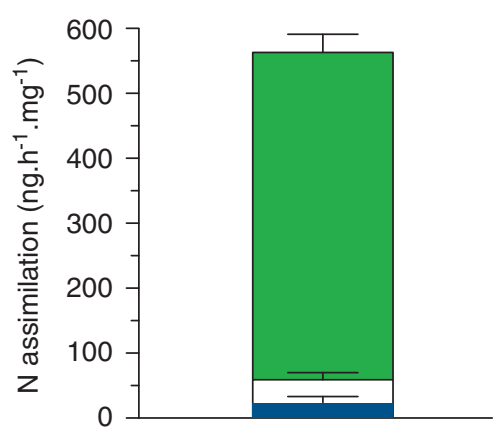

Figure 4 Cell specific nitrogen assimilatory capacity in the reefbuilding coral $A$. aspera in response to a pulse of seawater enriched in ${ }^{15} \mathrm{~N}$-ammonium. The total nitrogen uptake rate was calculated in dinoflagellate symbionts (green), gastrodermal host cells (blue) and epidermal host cells (white) by normalizing the ${ }^{15} \mathrm{~N}$-incorporation to the average nitrogen content (\% of dry mass) of the animal tissue or the dinoflagellate symbionts and to the time of incubation according to the equation of Dugdale and Wilkerson (1986) as described (Supplementary Text S1). The boxes indicate the mean value \pm s.d. (total number of cells analyzed = 15 for dinoflagellate cells; 52 for coral epidermal host cells; 51 for coral host gastrodermal cells).

ammonium, the dinoflagellate symbionts providing the most active, but not the only site of fixation.

Symbiotic Symbiodinium live within the cells of the coral gastrodermis. Consequently, their capacity to incorporate nitrogen during a pulse of enriched seawater depends not only on their assimilatory capabilities but also on the passage of nitrogen from the seawater through the coral host tissue to the vacuole containing the dinoflagellate cells. D'Elia et al. (1983) inferred that the transport of nitrogen occurs principally by diffusion down a concentration gradient created by localized deficit of ammonium in the coral host tissue surrounding symbiotic dinoflagellates. It is possible then that the coral host maintains this concentration gradient in the areas surrounding symbiotic dinoflagellates by rapidly fixing ammonium into amino acids, which can be used by the coral or transferred to the algal cells later on. This hypothesis has been somehow neglected so far (but see: Miller and Yellowlees, 1989; Wang and Douglas, 1998; Yellowlees et al., 2008) based on evidence that GS/GOGAT cycle, the fastest route for incorporating ammonium into amino acids through glutamate, is not widespread in animals. However, recent studies demonstrated that GS/GOGAT cycle is active in several metazoans (Scaraffia et al., 2005; Hansen and Moran, 2011) and our analyses using BLAST algorithm (Altschul et al., 1990) indicate that transcripts encoding proteins with high similarities to the domains of GOGAT are present in two cnidarian genomes (Nematostella vectensis (Sullivan et al., 2006), genBank accession number: XP_001630774.1; Acropora digitifera (Shinzato et al., 2011), http://marinegenomics.oist.jp/acropora _digitifera/, gene ID: aug_v2a.08445.t1; Supplementary Table S2). In congruence with the rapid ${ }^{15} \mathrm{~N}$-enrichment observed in the coral tissue by 

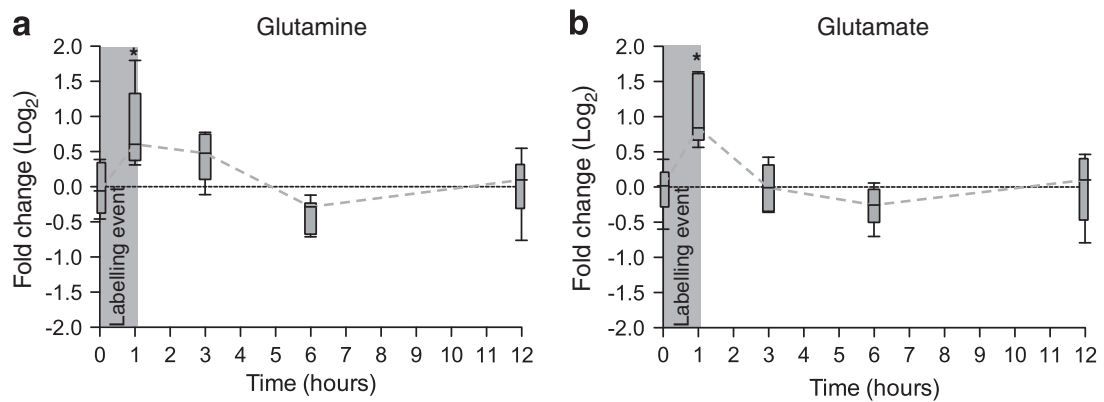

Figure 5 Effect of the pulse of ammonium-enriched seawater on Glutamine and Glutamate abundance in symbiotic dinoflagellate cells within the reef-building coral Acropora aspera. Fold change in Glutamine (a) and Glutamate (b) $\left(\log _{2}\right.$ ratio of labeled samples divided by the pool of control samples). The box-whisker plot separates the data into quartiles, with the top of the box defining the 75th percentile, the line within the box giving the median, and the bottom of the box showing the 25th percentile. The upper 'whisker' defines the 95th percentile; the lower whisker, the 5 th percentile $(N=6$ coral branches per time point per treatment). *Significant difference ( $t$-test, $P<0.05$ ) between treatment and control for the same time point.

NanoSIMS after the pulse of ${ }^{15} \mathrm{~N}$-ammonium enriched seawater, the results of these BLAST searches suggest that coral hosts could use GS/GOGAT cycle to rapidly fix seawater-derived ammonium into amino acids. By doing so, the coral host would not only protect its tissue from high and toxic environmental ammonium load, but would also facilitate the transport of ammonium to the dinoflagellate cells, thus enabling a more efficient use of the pulse of enriched seawater. Once ammonium is present in the direct environment of symbiotic dinoflagellates, its assimilation depends on the physiological properties of the algae including (i) the activity of ammonium transporters, as suggested by the presence of several sequences encoding such transporters in an expressed sequence tag library from Symbiodinium (Leggat et al., 2007) and (ii) the concerted action of several enzymes in dinoflagellate cells such as glutamate dehydrogenase, GS and GOGAT (Summons and Osmond, 1981; Summons et al., 1986).

\section{Metabolic fate of ammonium assimilated by dinoflagellate symbionts}

The main ammonium assimilatory pathway in dinoflagellate is via the GS/GOGAT cycle (Summons and Osmond, 1981; Summons et al., 1986; Rahav et al., 1989; Roberts et al., 1999) in which GS first transfers ammonium to glutamate to produce glutamine and GOGAT then completes the cycle by catalysing the conversion of glutamine and 2-oxoglutarate to produce Glutamate (Falkowski et al., 1993; Roberts et al., 1999; Inokuchi et al., 2002). The abundance of Glutamine and Glutamate is therefore supposed to be a sensitive indicator of assimilation of nitrogen following uptake of ammonium by dinoflagellate (Flynn et al., 1994). Physiological measurements supports significant incorporation of ammonium by $A$. aspera dinoflagellate symbionts via GS/GOGAT, with a relative increase in Glutamine and Glutamate detected at the end of the $1 \mathrm{~h}$-pulse of $\mathrm{NH}_{4} \mathrm{Cl}(1.9 \pm 0.8$ and $2.1 \pm 0.7$-fold increase in Glutamine and Glutamate respectively at $1 \mathrm{~h}, t$-test, $P \leqslant 0.05$, Figure 5 ) followed by a decrease back to control level from $3 \mathrm{~h}$ onward indicating rapid mobilization of these amino-acids. Because Glutamine and Glutamate are the amino group donors in the formation of numerous biosynthetic products, their metabolic fates could then follow several pathways within coral-dinoflagellate symbiosis: (i) Glutamine and Glutamate could be transferred directly to the coral host (Hypothesis 1, Figure 6); (ii) Glutamine and Glutamate could be used by the symbionts to synthesize other amino acids and proteins that could be later mobilized within symbiont cell compartment or translocated to the coral host (Hypothesis 2, Figure 6) (Wang and Douglas, 1999); (iii) Glutamate could be directly used by the symbionts to produce the key Krebs cycle intermediate $\alpha$-ketoglutarate that, in turn, can be used to stimulate ATP production (Hypothesis 3, Figure 6) or (iv) Glutamine could be subsequently incorporated by the dinoflagellate through the purine pathway to form derived compounds with high nitrogen content, such as uric acid, that could be stored and later mobilized when nitrogen acquisition may be limited (Hypothesis 4, Figure 6) (Clode et al., 2009). Because of ${ }^{15} \mathrm{~N}$-enrichment in dinoflagellate cells did not decrease over the $11 \mathrm{~h}$ chase period, our data are more consistent with the storage and mobilization of ${ }^{15} \mathrm{~N}$-ammonium derived compounds within the symbiont cell compartment (Hypotheses 2, 3 and 4, Figure 6), than with the rapid translocation of ${ }^{15} \mathrm{~N}$-ammonium derived compounds from the symbiont to the host (Hypothesis 1, Figure 6). However, the design of the pulse-chase experiment in this study ( $11 \mathrm{~h}$-chase period) focused on the early steps of ammonium assimilation in the coral-dinoflagellate symbiosis. Further, a small, but significant, ${ }^{15} \mathrm{~N}$-enrichment was detected in the coral tissue during the last $6 \mathrm{~h}$ of the chase, therefore, a delayed release of amino acids from the dinoflagellate symbiont, as proposed by Wang and Douglas (Wang and Douglas, 1999), has to be considered. In this respect, future studies focusing on the exchange of nitrogen-derived compounds within this symbiosis need to include labeling 


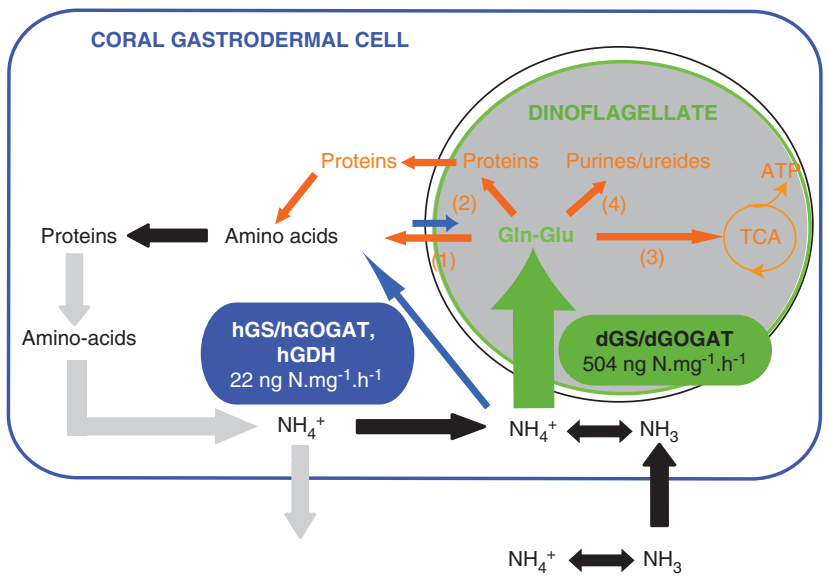

Figure 6 Model of ammonium assimilation in the coraldinoflagellate symbiosis. Green and blue arrows highlight the capacity of dinoflagellate symbionts and coral gastrodermal cells to fix nitrogen within the symbiosis following a pulse of ammonium enriched seawater as demonstrated by NanoSIMS analysis of ${ }^{15} \mathrm{~N}$-labeled tissue. Blue arrows denote the main hypothesis for ammonium incorporation by the coral host using GS/GOGAT cycle and GDH and potential transfer to the dinoflagellate symbionts. Orange arrows indicate the main hypotheses for the metabolic fates of ammonium-derived products in the dinoflagellates symbiont and their potential transfer to the coral host: (1) direct transfer of ammonium derivedglutamine (Gln) and glutamate (Glu) to the coral host; (2) incorporation of ammonium derived-glutamine and -glutamate into other amino acids or proteins that that could be later mobilized within symbiont cell compartment or translocated to the coral host; (3) conversion of ammonium derived-glutamate by the symbiont to produce key intermediates of the Krebs cycle (TCA) further used for energy production and (4) incorporation of ammonium derived-glutamine by the symbiont into the purine pathway to form stores of derived compounds with high nitrogen content, such as uric acid. dGS, dinoflagellate symbiont glutamine synthetase; dGOGAT, dinoflagellate symbiont glutamine: 2-oxoglutarate aminotransferase; hGS, coral host glutamine synthetase; hGOGAT, coral host glutamine:2-oxoglutarate aminotransferase; hGDH, coral host glutamate dehydrogenase. Gray arrows indicate proteins catabolism and excretion pathways.

experiments with extended chase period and NanoSIMS imaging combined with high performance liquid chromatography and mass spectrometry analysis, in order to precisely analyse the identity and the sequence of production of these compounds. In this way, the metabolic interactions between dinoflagellate symbionts and their coral host will be fully characterized providing a basis to understand the effect of abiotic changes on the nutritional function of this important symbiosis.

\section{Conclusion}

In conclusion, we describe the dynamic incorporation of ammonium in the symbiotic coral $A$. aspera by combining a short-term pulse-chase isotopic labeling with high spatial resolution ion microprobe imaging. Although this procedure might be improved by using advanced sample preparation technology, it paves the way for future investigations into metabolic interactions in corals and other models of symbiosis. Given the importance of nitrogen in cell maintenance, growth and functioning, the observed capabilities of both dinoflagellate and animal cells to rapidly fix nitrogen from seawater enriched in ammonium (in less than $1 \mathrm{~h}$ ) may be a key component of the nutritional function of symbiotic cnidarians. Further, our data clearly demonstrate significant differences in the assimilatory abilities of coral and dinoflagellate cells, the symbionts fixing 14 to 23 times more nitrogen than coral host cells in response to a pulse of ammoniumenriched seawater. This particular model of ammonium assimilation may vary significantly depending on several factors, such as the nitrogen regimes, the presence of associated microbial communities and, ultimately, the different host-dinoflagellate combinations. Nevertheless, further research combining isotopic labeling experiment with extended chase periods, NanoSIMS imaging and chemical profile analysis should enable us to unveil the fate of nutrients and to test how nutritional interactions changes when corals and their dinoflagellate symbionts are exposed to different environmental conditions. Given the fact that Symbiodinium are widely distributed in the photic zone of tropical and subtropical sea waters, and live symbiotically with numerous other reef organisms such as soft corals, sea-anemones, jellyfish, giant clams, sponges, foraminifera or nudibranchs, NanoSIMS isotopic imaging has the potential to dramatically improve our understanding of the metabolic activities and the nutritional interactions that lie at the very heart of coral reef ecosystems.

\section{Acknowledgements}

The authors would like to thank T Miard for assistance during corals samples collection and experimental set up at Heron Island Research Station. We also thank Rick Webb and Robyn Simpson for support with sample processing for TEM analysis. This work was supported by a Marie Curie International Outgoing Fellowship to MP, a CNRS interdisciplinary program to ID-C, the ARC Centre for Excellence for Coral Reef Studies (to OHG and SD) and the European Research Council through Advanced Grant 246749 (BIOCARB) to AM. The National NanoSIMS facility at the Muséum National d'Histoire Naturelle was established by funds from the CNRS, Région Île de France, Ministère délégué à l'Enseignement supérieur et à la Recherche and the Muséum itself. Furthermore, the authors thank two anonymous reviewers for their valuable and constructive comments on the first version of the manuscript, which helped improve the quality of this paper.

\section{References}

Altschul SF, Gish W, Miller W, Myers EW, Lipman DJ. (1990). Basic local alignment search tool. J Mol Biol 215: 403-410. 
Beman JM, Roberts KJ, Wegley L, Rohwer F, Francis CA. (2007). Distribution and diversity of archaeal ammonia monooxygenase genes associated with corals. Appl Environ Microbiol 73: 5642-5647.

Brahmi C, Meibom A, Smith D, Stolarski J, AuzouxBordenave S, Nouet J et al. (2010). Skeletal growth, ultrastructure and composition of the azooxanthellate scleractinian coral Balanophyllia regia. Coral Reefs 29: 175-189.

Bythell JC. (1990). Nutrient uptake in the reef-building coral Acropora palmata at natural environmental concentrations. Mar Ecol Prog Ser 68: 65-69.

Clode PL, Saunders M, Maker G, Ludwig M, Atkins CA. (2009). Uric acid deposits in symbiotic marine algae. Plant Cell Environ 32: 170-177.

Clode PL, Stern RA, Marshall AT. (2007). Subcellular imaging of isotopically labeled carbon compounds in a biological sample by ion microprobe (NanoSIMS). Microsc Res Tech 70: 220-229.

Dattagupta S, Schaperdoth I, Montanari A, Mariani S, Kita N, Valley JW et al. (2009). A novel symbiosis between chemoautotrophic bacteria and a freshwater cave amphipod. ISME J 3: 935-943.

Davy SK, Withers KJT, Hinde R. (2006). Effects of host nutritional status and seasonality on the nitrogen status of zooxanthellae in the temperate coral Plesiastrea versipora (Lamarck). J Exp Mar Biol Ecol 335: 256-265.

D’Elia CF, Domotor SL, Webb KL. (1983). Nutrient uptake kinetics of freshly isolated zooxanthellae. Mar Biol 75: 157-167.

Dugdale RC, Wilkerson FP. (1986). The use of $15 \mathrm{~N}$ to measure nitrogen uptake in eutrophic oceans; experimental considerations. Limnol Oceanogr 6: 673-689.

Falkowski PG, Dubinsky Z, Muscatine L, McCloskey L. (1993). Population control in symbiotic corals. BioScience 43: 606-611.

Fautin DG, Mariscal RN. (1991) Cnidaria:Anthozoa, vol. 2. Wiley: New York.

Flynn KJ, Jones KJ, Raine R, Richard J, Flynn K. (1994). Use of intracellular amino-acid analysis as an indicator of the physiological status of natural dinoflagellate populations. Mar Ecol Prog Ser 103: 175-186.

Foster RA, Kuypers MMM, Vagner T, Paerl RW, Musat N, Zehr JP. (2011). Nitrogen fixation and transfer in open ocean diatom-cyanobacterial symbioses. ISME $J \mathbf{5}$ : 1484-1493.

Grover R, Maguer J-F, Allemand D, Ferrier-Pages C. (2008). Uptake of dissolved free amino acids by the scleractinian coral Stylophora pistillata. J Exp Biol 211: 860-865.

Grover R, Maguer J-F, Reynaud-Vaganay S, Ferrier-Pages C. (2002). Uptake of ammonium by the scleractinian coral Stylophora pistillata: effect of feeding light, and ammonium concentrations. Limnol Oceanogr 47: 782-790.

Hansen AK, Moran NA. (2011). Aphid genome expression reveals host-symbiont cooperation in the production of amino acids. Proc Natl Acad Sci USA 108: 2849-2854.

Houlbreque F, Meibom A, Cuif J-P, Stolarski J, Marrocchi Y, Ferrier-Pages C et al. (2009). Strontium-86 labeling experiments show spatially heterogeneous skeletal formation in the scleractinian coral Porites porites. Geophys Res Lett 36: L04604.

Inokuchi R, Kuma K-I, Miyata T, Okada M. (2002). Nitrogen-assimilating enzymes in land plants and algae: phylogenic and physiological perspectives. Physiol Plant 116: 1-11.
Koop K, Booth D, Broadbent A, Brodie J, Bucher D, Capone $\mathrm{D}$ et al. (2001). ENCORE: the effect of nutrient enrichment on coral reefs. Synthesis of results and conclusions. Mar Pollut Bull 42: 91-120.

Kuypers MM. (2007). Microbiology. Sizing up the uncultivated majority. Science 317: 1510-1511.

Lechene C, Hillion F, McMahon G, Benson D, Kleinfeld AM, Kampf JP et al. (2006). High-resolution quantitative imaging of mammalian and bacterial cells using stable isotope mass spectrometry. J Biol 5: 20.

Lechene CP, Luyten Y, McMahon G, Distel DL. (2007). Quantitative imaging of nitrogen fixation by individual bacteria within animal cells. Science 317: 1563-1566.

Leggat W, Hoegh-Guldberg O, Dove S, Yellowlees D. (2007). Analysis of an EST library from the dinoflagellate (Symbiodinium sp.) symbiont of reef-building corals. J Phycol 43: 1010-1021.

Lipschultz F, Cook CB. (2002). Uptake and assimilation of $15 \mathrm{~N}$-ammonium by the symbiotic sea anemones Bartholomea annulata and Aiptasia pallida: conservation versus recycling of nitrogen. Mar Biol 140: 489-502.

Meibom A, Cuif J-P, Hillion F, Constantz BR, Juillet-Leclerc A, Dauphin Y et al. (2004). Distribution of magnesium in coral skeleton. Geophys Res Lett 31: L23306.

Meibom A, Cuif J-P, Houlbreque F, Mostefaoui S, Dauphin Y, Meibom KL et al. (2008). Compositional variations at ultra-structure length scales in coral skeleton. Geochim Cosmochim Ac 72: 1555-1569.

Meibom A, Mostefaoui S, Cuif J-P, Dauphin Y, Houlbreque F, Dunbar R et al. (2007). Biological forcing controls the chemistry of reef-building coral skeleton. Geophys Res Lett 34: L02601.

Miller DJ, Yellowlees D. (1989). Inorganic nitrogen uptake by symbiotic marine cnidarians: a critical review. Proc $R$ Soc B 237: 109-125.

Mohideen W, Sayeeda W, Jason JD. (1990). Nitrification in reef corals. Limnol Oceanogr 35: 725-730.

Musat N, Halm H, Winterholler B, Hoppe P, Peduzzi S, Hillion $\mathrm{F}$ et al. (2008). A single-cell view on the ecophysiology of anaerobic phototrophic bacteria. Proc Natl Acad Sci USA 105: 17861-17866.

Muscatine L. (1990). The role of symbiotic algae in carbon and energy flux in reef corals. In: Dubinsky Z (ed). Coral reefs. Elsevier: Amsterdam, pp 75-87.

Rahav O, Dubinsky Z, Achituv Y, Falkowski PG. (1989). Ammonium metabolism in the zooxanthellate coral, Stylophora pistillata. Proc $R$ Soc B 236: 325-337.

Reynaud S, Ferrier-Pages C, Meibom A, Mostefaoui S, Mortlock R, Fairbanks R et al. (2007). Light and temperature effects on $\mathrm{Sr} / \mathrm{Ca}$ and $\mathrm{Mg} / \mathrm{Ca}$ ratios in the scleractinian coral Acropora sp. Geochim Cosmochim Acta 71: 354-362.

Roberts JM, Davies PS, Fixter LM, Preston T. (1999). Primary site and initial products of ammonium assimilation in the symbiotic sea anemone Anemonia viridis. Mar Biol 135: 223-236.

Roberts JM, Fixter LM, Davies PS. (2001). Ammonium metabolism in the symbiotic sea anemone Anemonia viridis. Hydrobiologia 461: 25-35.

Scaraffia PY, Isoe J, Murillo A, Wells MA. (2005). Ammonia metabolism in Aedes aegypti. Insect Biochem Molec Biol 35: 491-503.

Sheppard CRC, Davy SK, Pilling GM. (2009). The Biology of Coral Reefs. Oxford University Press: New York.

Shinzato C, Shoguchi E, Kawashima T, Hamada M, Hisata $\mathrm{K}$, Tanaka M et al. (2011). Using the Acropora 
digitifera genome to understand coral responses to environmental change. Nature 476: 320-324.

Smart KE, Smith JAC, Kilburn MR, Martin BGH, Hawes C, Grovenor CRM. (2010). High-resolution elemental localization in vacuolate plant cells by nanoscale secondary ion mass spectrometry. Plant J 63: 870-879.

Spalding MD, Ravilious C, Green EP. (2001). World atlas of coral reefs. University of California Press: Berkley, CA.

Stimson J, Kinzie RA. (1991). The temporal pattern and rate of release of zooxanthellae from the reef coral Pocillopora Damicornis (Linnaeus) under nitrogenenrichment and control conditions. J Exp Mar Biol Ecol 153: 63-74.

Stolarski J, Meibom A, Przeniosło R, Mazur M. (2007). A cretaceous scleractinian coral with a calcitic skeleton. Science 318: 92-94.

Sullivan JC, Ryan JF, Watson JA, Webb J, Mullikin JC, Rokhsar D et al. (2006). StellaBase: the Nematostella vectensis genomics database. Nucleic Acids Res 34: D495-D499.

Summons RE, Boag TS, Osmond CB. (1986). The effect of ammonium on photosynthesis and the pathway of ammonium assimilation in Gymnodinium microadriaticum in vitro and in symbiosis with tridacnid clams and corals. Proc $R$ Soc B 227: 147-159.

Summons RE, Osmond CB. (1981). Nitrogen assimilation in the symbiotic marine alga Gymnodinium microadriaticum: direct analysis of $15 \mathrm{~N}$ incorporation by gc-ms methods. Phytochemistry 20: 575-578.

Swanson R, Hoegh-Guldberg O. (1998). Amino acid synthesis in the symbiotic sea anemone Aiptasia pulchella. Mar Biol 131: 83-93.
Szmant AM, Ferrer LM, FitzGerald LM. (1990). Nitrogen excretion and $\mathrm{O}: \mathrm{N}$ ratios in reef corals: evidence for conservation of nitrogen. Mar Biol 104: 119-127.

Venn AA, Loram JE, Douglas AE. (2008). Photosynthetic symbioses in animals. J Exp Bot 59: 1069-1080.

Wagner M. (2009). Single-cell ecophysiology of microbes as revealed by raman microspectroscopy or secondary ion mass spectrometry imaging. Annu Rev Microbiol 63: 411-429.

Wang J, Douglas A. (1998). Nitrogen recycling or nitrogen conservation in an alga-invertebrate symbiosis? J Exp Biol 201: 2445-2453.

Wang JT, Douglas AE. (1999). Essential amino acid synthesis and nitrogen recycling in an alga-invertebrate symbiosis. Mar Biol 135: 219-222.

Wegley L, Edwards R, Rodriguez-Brito B, Liu H, Rohwer F. (2007). Metagenomic analysis of the microbial community associated with the coral Porites astreoides. Environ Microbiol 9: 2707-2719.

Wilkerson FP, Muscatine L. (1984). Uptake and assimilation of dissolved inorganic nitrogen by a symbiotic sea anemone. Proc $R$ Soc B 221: 71-86.

Yellowlees D, Rees T, Fitt W. (1994). Effect of ammoniumsupplemented seawater on glutamine synthetase and glutamate dehydrogenase activities in host tissue and zooxanthellae of Pocillopora damicornis and on ammonium uptake rates of the zooxanthellae. Pacific Science 48: 291-295.

Yellowlees D, Rees TA, Leggat W. (2008). Metabolic interactions between algal symbionts and invertebrate hosts. Plant Cell Environ 31: 679-694.

Supplementary Information accompanies the paper on The ISME Journal website (http://www.nature.com/ismej) 